\title{
Voluntarism as Social Capital of Community Radio Management: a Case Study in Jarik III Cirebon
}

\author{
Dede Lilis $\mathrm{Ch}^{\mathbf{1}}$, M. Rochim ${ }^{1}$, Nova Yuliati ${ }^{1}$ \\ ${ }^{1}$ Communication Science Program, Faculty of Communication Science, \\ Universitas Islam Bandung
}

DOI: http://dx.doi.org/10.15294/komunitas.v8i1.4516

Received : 24 November 2015; Accepted: 22 March 2015; Published: 31 March 2016

\begin{abstract}
Community radio networking (Jarik) III Cirebon is the affiliation of community radio in Cirebon, Kuningan, Majalengka and Indramayu regencies. Jarik III consists of 11 community radios. Besides broadcasting, Jarik is active in social action. They have been defending people especially in human trafficking and domestic violence cases. Based on voluntarism perspective, this article elaborates how those radios mitigate the society's issue. This article was based on research through qualitative method using case study. The data was obtained through interview, observation, and documentation with three community radio FM administrators, namely Baina FM, Bhuana FM, and Caraka FM. The finding of the study shows that the background of the establishment, purpose and community radio operations are based on socio-demographic condition of their own community; societybased service becomes an administrator community radio's spirit; and voluntarism underlying administrator performance of community radio helps overcoming people's problem.
\end{abstract}

Keywords: community; community radio; community-based service; voluntarism

\section{INTRODUCTION}

Speaking of community radio which is commonly abbreviated as Rakom (Radio Komunitas), some people often imagine about cramped radio studios, makeshift equipments and only short-lasted broadcasting programs, unprofessional broadcasters, and "black radio" label. Indeed, the picture is a portrait of several radios that emerge from the grassroots level.

There are a number of reasons why society needs community radio. Birowo, Prakoso and Nasir in their book "Mengapa Radio Komunitas" propose the following reasons: (1) to express opinions and interests because community act as information producer or creator, and (2) because not all people can reach the existing broadcasting media. There are still many members of society who are not sufficient in accessing public mass media exposure. Those who live in remote areas, rural areas, small islands, and areas which are far from broadcasting television or radio cannot enjoy the mass media as easy as their counterpart or any other strategic places (Birowo, Prakoso and Nasir 2007).

Therefore, in November 2005, AMARC as an international association for community radio which has more than 3000 members from 116 countries conducted a congress in Jakarta by creating the "Jakarta Declaration" which strongly urged the government to provide conducive regulations to the development of community radio throughout the regions because Rakom plays a central role in the process of democratization and development within the country.

After the New Order, the community radio began to emerge and develop in various regions. In Indonesia, until 2013, there were 19 JRK in provincial areas which had joined Indonesian Community Radio
Corresponding author :

Address: Jalan Tamansari No. 1 Bandung 40116

Email : delilisubandy@gmail.com,

Telp : +628122189097
(C) 2016 Semarang State University. All rights reserved p-ISSN 2086 - 5465 | e-ISSN 2460-7320 
Network (JRKI). West Java was the province with the highest number of community radio as compared to the other provinces. There were 65 community radios that had received operating licenses and spreading in various cities and counties.

Of all regions in West Java, Cirebon is an area that continues to develop its community radio and join in a network known as the Community Radio Network (Jarik) III Cirebon, consisting of 11 community radios and spreading across Cirebon, Kuningan, Majalengka and Indramayu regencies. ${ }^{1}$

The interesting part of Jarik is that they are not only concerned with the world of broadcasting, but also are active in social services and care about the problems that occur in the community, for example, Rakom receives and assists several cases of migrant workers affecting people around $\mathrm{Ci}$ rebon. This is due to the lack of complaint posts from Indonesian Migrant Workers (BMI) and the trend begins to grow in the community to report cases through Rakom. Therefore, it makes the board of Jarik III Cirebon to do all they can to assist the mitigation of cases which are reported.

Jarik III Cirebon also joins the antitrafficking community network (amulet) consisting of non-governmental organizations (NGOs) throughout the region III Cirebon. Hence, they have prioritized migrant workers through community radio. In addition, Rakom is also the initiator of the establishment of Rural Building Movement (GDM). Meanwhile, to improve the capability of broadcasting, Rakom managers also attend various trainings conducted by various parties.

The phenomenon of Jarik III Cirebon further confirms that Rakom is a potential broadcasting institution which must be developed and studied seriously by the scientific approach for the contribution to the development of grassroots media.

The urgency of this study is in accordance with the statement of Edwin Jurriens School of Asian, African, and Amerindian Studies Leiden University who said that, "Since the reform, the world of radio in In1 http://jrkjawabarat.blogspot.com/ donesia underwent important changes. One new development is the emergence of community radio which serves as an alternative to the state radio and private radio. However, until now, community radio phenomenon is only discussed in guidebooks or NGO brochures, and they have not received any scientific attention "(Jurriens, 2003: 116-117). Moreover, until now, from the existing community radios, almost all of them are non-governmental radios with the principle of management: of, by, for, and about the community. Of course, this Rakom development must not be abandoned. In addition, it currently begins to provide a lot of benefits and strategic role for the community.

Therefore, the basis of the voluntarism perspective in this study is intended to further evaluate community radio management of Jarik III Cirebon in alleviating the problems of society with a focus on describing and mapping the following matters: (1) the background of the establishment, purpose and operation of community radio of Jarik III Cirebon; (2) the spirit of community radio managers in meeting the needs of the community; and (3) the principle of Rakom manager's performance in helping to mitigate community issues.

In order to make the exploration to contextual with the findings of the study, a comprehensive literature review of the main concepts will be conducted beforehand. The term community is related to many phenomena, interpretation patterns, and associations. If it is interpreted as a form of collectivity, according to Victor Azariah, community usually refers to: (1) a group whose members occupy physical space or to be in the same geographic area, neighborhood, village or town; or (2) a group whose members have similar traits which are usually collected by a sense of belonging, or can also by certain social ties and interactions that make the group as a social entity of its own, such as the tribe or ethnic (Azariah 200o, p.145).

The term of community in this article includes two interpretations, the community in geographical sense where the members live in a village, and the community in terms of social interaction between members and 
the bond that generates their sense of belonging. This sense of belonging is relevant to the establishment of community radio in a village that initially has been established and operated by NGOs. Community radio is a radio that belongs to the community. Moreover, the principle of operation of community radio is also based on the principle: of, by, for, and about the community.

In the media landscape, community radio is one of the alternative media. The typology of alternative media approach is based on the view of Anthony Giddens (1984) who divided between objective and subjective social theories. According to him, the object is the structure of society which is defined as "the rules and resources that have been implicated in social reproduction. Hence, it is stable in crossing the time and space" (Giddens 1984 in Sandoval 2009, p. 3), meanwhile, subject is understood as "the knowledgeable human agent" (Giddens 1984: xx in Sandoval 2009, p.3).

This article examines the community radio from the standpoint of the subjective approach that focuses more on media actors and how they create alternative media. Media in this approach can have the effect of social emancipator if it contributes to the democratization of access to media production by giving people voice they need. Therefore, subjective approach demonstrates an understanding of alternative media as a participatory media.

There are many approaches to the alternative media. The discourse on community media is also widely oriented towards the practice of media actors. Community media approaches -one of which is radio community- are subjective approach because they focus on a participatory access to the media production and empowerment of individuals. In this context, the media community is understood as a medium that serves a community of a specific geographical or community's interest, as well as allows non-professionals to actively engage in the production, organization, and management of media (Lewis 1976, p.61; Jankowski 2003, p.8; Coyer 2007; KEA 2007, p.1; Peissl and Tremetzberger 2008, p.3 in Sandoval 2009, p.5).

According to Act No. 32/2002, there are three types of radio in Indonesia, namely (1) public broadcasting radio, (2) commercial broadcasting radio and (3) community broadcasting radio. Community radio is distinguished by public radio on two characteristics: (1) community radio serves the interests of communities that are geographically limited, while the public radio serves the large-scale interests and geographically covers the entire national territory, (2) community radio relies on legal entities on loyal proprietary, funding and management of community, while the public radio receives funding from the state official.

Some results of previous research also show that community radios have a positive impact for the community. Haryanto and Ramdojo (2009, p.126-127) describe that the results of a survey from Rakom in five regions: West Java, Central Java, Yogyakarta, West Nusa Tenggara and Southeast Sulawesi, as well as the FGD in Yogyakarta and Jakarta in 2008 reveal that the strategic role of community radio includes: as a medium of information and entertainment, advocacy, community assistance, and empowerment local culture; as an alternative medium of community which is closer to the heart of their audience than the mainstream media because it involves the problems of citizens such as politics, health, and welfare; as the stakeholders considering community radios have great potential to produce alternative media that is contextual to the interests of citizens who often do not get the information that is appropriate to their needs.

Later, Edwin Jurriens' study in the Journal of Anthropology Indonesia 72 (2003), entitled " Radio Komunitas di Indonesia: 'New Brechtian Theatre' di Era Reformasi?" examines the growing community radios in Central Java. His research concludes that community radio in Indonesia emerges as an alternative between public radio and commercial radio after the fall of Soeharto Era in 1998. According to him, two important things from Rakom is that community radios give all community members access to same information and encourage 
them to actively participate in the management and broadcast production. These views society encourages self-awareness and sense of community. The existence of community radio show that the rights and obligations of the democratic Indonesian society encourages social groups to express themselves without the intervention of others and contributes to the diversity of Indonesian media.

\section{RESEARCH METHODS}

This paper was based on research using qualitative methods to obtain findings with natural background and was oriented to the managers of community radio as an actor, as Stake said, "qualitative method is based on the premise that the reality creates in social interaction (socially constructed), and therefore should be conceived of the subject itself. "(Denzin and Lincoln, 2000 in Rochwulaningsih, 2015:3).

Further, Denzin and Lincoln also reveal that qualitative method, "examines the things that are in their natural environment, trying to understand, or interpret phenomena based on the meanings that people give to such matters. Conventionally, qualitative method tends to be associated with the desire of researchers to examine the meaning, context, and a holistic approach to the phenomenon "(Mulyana and Solatun 2007, p.5-6).

The qualitative approach used in this study was case study. This choice was made in order to be able to describe reality in a comprehensive manner from a variety of sources, as John W. Creswell disclosed,

"Case study research is a qualitative approach in which the investigator explore a real-life, contemporary bounded system (a case) or multiple bounded systems (cases) over time, through detailed, in-depth data collection involving multiple sources of information (e.g. observation, interview, audiovisual material, and documents and reports), and reports a case description and case themes. The unit of analysis in the study might be multiple cases (a multisite study) or a single case (a within-site study) (Creswell 2013, p.97).
A case study is a qualitative approach in which the investigator explores real life, either in the form of a case or multiple cases all the time in detail, a collection of in-depth data includes sources of diversified information-such as observation, interviews, audiovisual material, documents and reports as well as reported a 'description of the case' and 'themes of the case'.

The unit of analysis in this study was a multi-case which reviewed the case in three community radio members Jarik III Cirebon, namely: Baina FM in Babakan Mulya Jalaksana village, Kuningan Regency, Bhuana FM in Cangkoak Dukupuntang Village, Cirebon Regency, and Caraka FM in Ciborelang Jatiwangi Village, Majalengka Regency. The informants were four people in the three Rakom who had served as chairmen and treasurers. Selection of informants was based on purposive sampling, i.e. those that were considered to be experienced management practices in their Rakom.

Meanwhile, the stages in the study were divided into four steps, namely: design, data collection, analysis, and reporting. Then, to explore the findings of techniques of data collection was conducted through interviews, observation, and documentation. Furthermore, to analyze the data, method of interactive data analysis by Miles and Huberman was used, including: data collection, data reduction, data presentation, and conclusion with the withdrawal or verification (Miles \& Huberman 1992, p.16-21).

\section{RESULTS AND DISCUSSION}

\section{The presence of Community Radio based on Socio-Demographic Back- grounds}

The socio-demographic backgrounds of society initiate the establishment, purpose and operation of community radio. This is a community radio which was born in the midst of society and driven by the needs of media on society at the grassroots level which they do not get from the mainstream media.

Based on the findings obtained three types of socio-demographic background of 
different communities on each Rakom as illustrated in Figure 1.

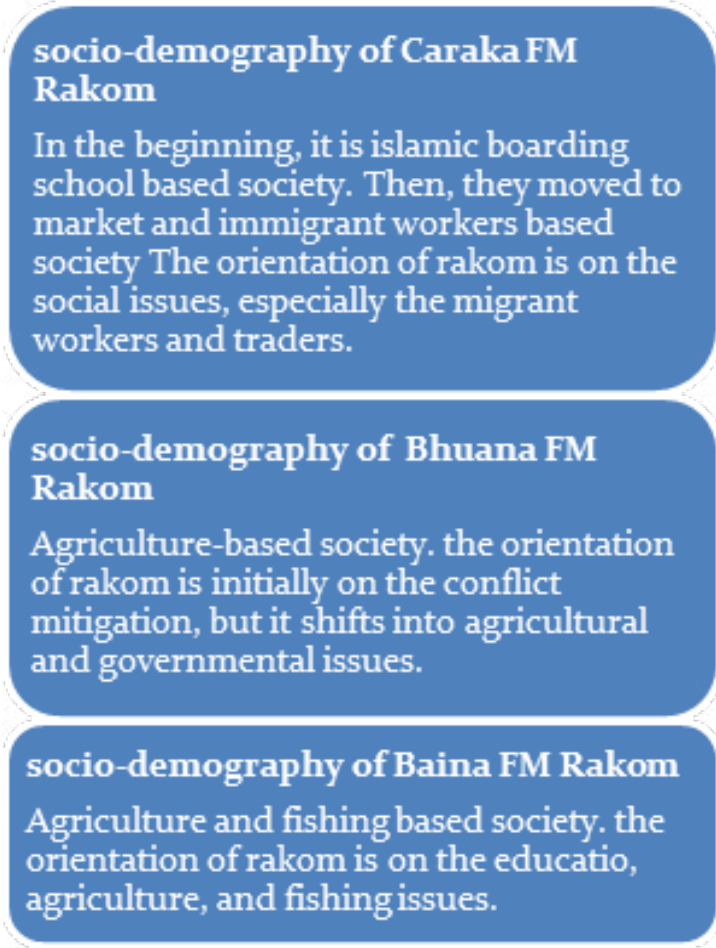

Figure 1. socio-demographic background of society and orientation of Rakom

The socio-demographic backgrounds greatly affect the purpose and orientation of Rakom because ideally, every Rakom involves communities in management and operation of Rakom. One of the descriptions of the community radio formulated in an anthology of stories about community radio initiative, A Passion for Radio, which is compiled by Bruce Girard (1992):

Community radio [is] a type of radio made to serve people; radio that encourage expression and participation and that values local culture. Its purpose is to give a voice to those without voices, the marginalized groups and to communities far from large urban centers, where the population is too small to attract commercial or largescale state radio (Girard 1992 in Jankowski 2002, p.7).

Further, Girard also said that "community radio is not only to participate in community life, but also allows the commu- nity to participate in the radio survival. This participation is at the level of ownership, programming, management, directors, and financial aspects "(Girard 1992, p.13 in Jankowski 2002, p.7).

Therefore, community radio has unique characteristics as compared to commercial radio. The typical focus of community radios according to the guidebooks community radio published by UNESCO (2001) is, "community radio trying to make the listener as the protagonist (main character) through their involvement in all aspects of management and production program, and by presenting them the program which will assist them in the development and social progress in their communities "(Fraser and Estrada 2001, p.15; Jurriens 2003, p.118; Francine Ch, Yuliati and Rochim 2009, p.149).

Carlos A. Arnaldo in Community Radio Handbook also reveals that, "Community radio is a process or a social event where members of the community join together to design, produce, and broadcast programs. Then, they take a leading role as actors in their own purposes" (Fraser and Estrada 2001). Ericka Tucker also views the same characteristics associated with the presence of community radio in a society. Through her research, she investigates radio stations communities in Developing Countries, USA and Europe, she reveals that Rakom voice the same thing, that "where there is community radio, then there is community involvement which can increase the capacity of the community to act as a check and balance on the power of government and corporate and to mobilize residents on community issues as well as to provide a forum to develop solutions for various problems "(Tucker 2013, p.412).

This means that the existence of community radio in the midst of society rests on its locality, as confirmed by Tanja E. Boschfounder of Bush Radio stations and radio trainer of UNESCO for Rakom, about "Sustaining community radio stations" as below,

"despite challenges around sustainability, community radio station are flourishing as concrete manifestations of an alter- 
native public sphere, with the increasing conglomeration of the ownership of masss media, the role of community radio becomes important. For more than fifty years radios has been the most appealing tool for participatory communication and development. Radio is the most potentially participatory medium and has its roots in the community, which guarantees that communication processes take the regional reality as a starting point (Bosch 2007 , p.29).

Community radio is clear evidence of an alternative form of public space especially with the conglomerate ownership of the mass media. Therefore, Rakom can serve as potential catalyst for participatory communication in the development of society because of its roots in the community will ensure the process of regional and local communication as the standpoint.

\section{Community-Based Social Services as Radio Community Management Spirit} There are differences between public broadcasters, commercial, and community. Public and commercial broadcasters include category that treats listener as an object, while community radio treats their listeners as subjects and participants who are involved in its implementation (Fraser \& Estrada 2001).

Different characters at the management practices of community radio in positioning the listener as a subject in the operation of the radio, either as a manager, announcer, and listeners, will raise awareness of the manager of Rakom that Rakom is born as conceived by the people and survive on the support of the community as well who have been marginalized by the media mainstream (mainstream media).

Marginalization exists when almost all mass media contain national and global exposures, so that people in rural areas are never touched by the media. This has led to public dissatisfaction in meeting the needs to access the media because there is no information closely related to their daily life as well as events and local issues that will assist communities in addressing various issues of life.

The presence of community radio, although it is less apt to be called as a panacea, but it is no exaggeration to say that Rakom has a strategic and potential function to meet the needs of information and entertainment in rural communities. This is because the content of Rakom is oriented to the needs of local communities and touched various issues their real lives.

Why content on community radio programs can help people? This is because it is based on the key elements of community radio concept of "access and participation" (Jurriens 2003, p.118). Access means that all community members have equal opportunity to receive broadcasts while participation means that the listeners are actively involved in the management and production of community radio broadcasting.

The closeness of the relationship between Rakom and society starts from the idea of the establishment, operation, and development of Rakom to survive. Without closeness of the relationship, then it is likely that a Rakom will not last long in the middle of society. To establish a close relationship between the community radio and society, the various ways are used by each Rakom to maintain its existence. Based on the resulting research prototype at three Rakom managers implement methods to gain the trust of the community, as illustrated in Figure 2.

Rakom conducts the methods through a variety of ways done by managers so that they are more trusted as a media which is oriented to the society in fulfilling their need to access the media. In addition, this method and the manager attempts make Rakom as media which is close to the audience, so the audience becomes part of it and feel to own it. The efforts made by the management of community radio are solely based on their spirit to provide community-based services.

Speaking of community-based services, Jim Ife and Frank Tesoriero (2008) tell the historical background underlying the development of this view as a new alternative in the development of society. In the long history of human life, there are many different institutions and mechanisms to meet 


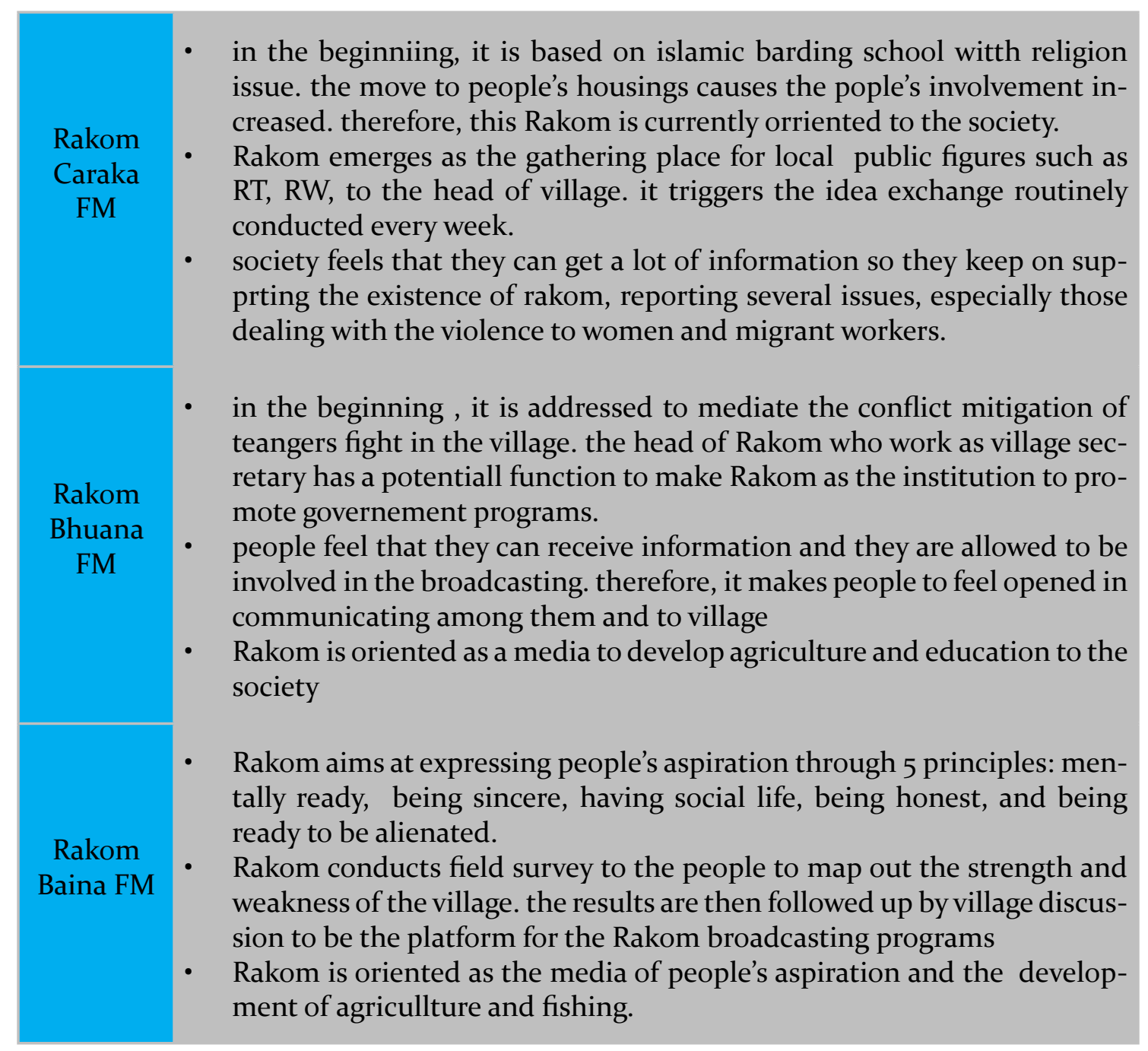

Figure 2. Several Methods which are implemented by Rakom in gaining public confidence

human needs. At a different time period, families, tribes, villages, places of worship, markets and countries have played important roles in the process of fulfilling human needs, often in combination. Each institution must have a dominant role in meeting human needs, but with the changing society, each agency is proven to be inadequate to meet the needs of the new order, although each institution still leaves an increasingly smaller role in subsequent times.

The crisis in the welfare state is merely one example of many historical transitions where the state as a place to put very high expectations, shows the inadequacy e at the time of the emergence of new forms of social structures, economic, and political (Ife \& Tesoriero 2008, p.25).
In situations like this, there is increased interest in community-based programs as an alternative mode of delivery of services of humanity and for the fulfillment of human needs fairly (Shragge 1990; Ife, 1993; Ewalt, Freeman \& Poole 1998; Frellin, 2001, in Ife \& Tesoriero 2008, p.25). After the family, places of worship, markets and countries, now may turn to 'community' which bear the main responsibility for delivering the provision of services in areas such as health, education, housing and welfare.

The term 'community-based' has been used in a variety of meanings. In the perspective of community development, community-based social services is a fundamental component of an alternative society, and has the potential to replace the existing system 
with something more powerful based on the principle of ecological sustainability and social justice / human rights (Ife \& Tesoriero 2008, p.218).

The essence of the approach to the service of humanity is that people must take responsibility not only to provide services, but also to identify the needs, planning services to those in need, priority setting in scope and among the services 'compete', and monitoring and evaluating programs. The people themselves who decide what is needed, how it should have been initiated, how it should be given and how it should be evaluated (Ife \& Tesoriero 2008, p.219).

Putting the primary responsibility for the provision of services to the local community means that society must use their own strength in terms of human resources and expertise. The service will also be designed and provided by and for the community. In this case, personal experience, local knowledge, understanding and local knowledge is appreciated.

Aside from the spirit of Rakom managers to perform community-based social service, Rakom also tries to build social values of society, such as the Baina FM Rakom which bases its Rakom as media aspirations of the people with the 5 principles of operation: being mentally ready, having a sincere soul, having a social life, being honest, and being prepared to be alienated. It can be concluded that Rakom can also serve as a disseminator of values, especially the values of which are built in the internal environment Rakom itself. It is already a form of character education at the managers and broadcasters of Rakom.

In a broad sense, Martadi (2010) states that the character education can be defined as the value of education, character education, moral education, education character that aim to develop the ability of learners to decide which is bad or good and embodies goodness in everyday life with a vengeance (Rev 2011, p.140-141). Although Rakom's existence is not as a direct educational institution, but the principle applied in Rakom is also a process of educating the character of managers and broadcasters in order to have a good human character.

In addition, people in the community are certainly living together and dynamics. The dynamics of community life in the small group level and in the context of the wider area are simultaneously constructing values and norms that are held in a common life (Maring, Hasugian and Kaligis 2015, p.109).

It is also in line with one of the classic descriptions of community radio is formulated in an anthology of stories about community radio initiatives-A Passion for Radiocompiled by Bruce Girard (1992) follows,

\begin{abstract}
Community radio [is] a type of radio made to serve people; radio that encourage expression and participation and that values local culture. Its purpose is to give a voice to those without voices, the marginalized groups and to communities far from large urban centers, where the population is too small to attract commercial or largescale state radio (Girard 1992 in Jankowski 2002, p.7). Radio community is one type of radio that is established to serve the community; Radio which presents the expression and public participation as well as the values of the local culture.
\end{abstract}

\section{Spirit of Voluntarism as The platform of Community Radio Management}

Girard says that "community radio is not only to participate in community life, but also allows the community to participate in the radio's survival. This participation is at the level of ownership, programming, management, directors, and financially "(Girard 1992, p.13 in Jankowski 2002, p.7).

Their participation or community involvement in the operation of Rakom is one of the key elements of the concept of community radio, as stated by Jurriens (2003, p.118), "the key element is the concept of community radio access and participation". Access means that all community members have equal opportunity to receive broadcasts while participation means that the listener is actively involved in the management and production of community radio broadcasting.

Community involvement in the management and production of these broadcasts 
is done in all community radios with the principle of "voluntary". Indeed, any member of the public should and could be involved in Rakom, but so far, no Rakom provides any incentives in the form of salary or wages to the managers and broadcasters. This is because sustainability Rakom is mostly funded by contributions from citizens or society. The condition is a prerequisite for the establishment of Rakom as defined in Law No. 32 of 2002 on broadcasting based on Rakom operation of non-governmental sources.

Not to mention, the Act prohibits Rakom for commercial advertisements. It is allowed to advertise only to restricted area such as public service announcements (PSAs). In fact, in the long history of the media business, its main source of advertisements media includes a variety of manufacturers. However, on the ground that Rakom is established not as a business institution, the community radio stations are not allowed to become a commercial institution.

Furthermore, in the Act No. 32/2002, community radio is called as broadcasting community under Article 21 paragraph 1 of Law No. 32/2002 which has these characteristics:

1) Legal Broadcasters in Indonesia

2) Independent

3) Non commercial

4) Low frequency

5) Limited regional reach

6) Serving the community only.

Then the objectives of the broadcasting community in article 21 paragraph 2 of Law No. 32/2002 are:

1) Not for profit or gain, or do not constitute part of the companies seeking profit.

2) To educate and promote the community in achieving prosperity by implementing programs that include: culture, education and information describing the identity of the nation.

This policy obviously limits Rakom to earn income, even for a broadcasting operating costs which are inevitable such as electricity costs. Meanwhile, socio-demographic and economic conditions of the community cannot be expected fully to citizens such as paying dues regularly in every month.

As a result, the manager is very empathetic with the conditions with no hope of financial reward from Rakom. Often, in order to finance the operations of broadcast technical matter, the managers have to expend funds from their private funds. Additionally, there is a concern from the managers toward their responsibility to society when asking the contributions from residents because for some managers, Rakom financial issue is a sensitive issue.

Until recently, the issue of the source of funds for most Rakom indeed becomes the biggest obstacle to survive and continue running. In the end, creativity and innovation created by managers of Rakom become one of the most powerful strategies to sustain their Rakom.

Survival strategies of Rakom that is often performed by a manager is to conduct cooperation with various parties, including government (the main one) and non-governmental agencies to conduct a variety of programs, both on-air and off-air such as to form cooperation that will have implications on the cost of production of radio and implementation of the activities that should be funded by the agency. Here, then, Rakom managers seek to set aside a little of the money they receive for operational costs of $R a$ kom. For example, Rakom cooperates with BKKBN to broadcast a variety of socialization of family planning programs. Broadcast material are generally provided by BKKBN, but how the material is packaged often is handed over to the managers of Rakom, for example in the form of advertising jingles, a short play or talk shows and so forth. Therefore, BKKBN should provide funds for production costs broadcasts. The small fund received is then set aside for operational costs of Rakom.

But of course, these funds are not always adequate because not all the time the cooperation exists. Under these conditions, the managers 'sacrifice' their personal funds for operational costs of Rakom when they are unsuccessful in asking for help from the people. Almost all managers of Rakom said 
that Rakom is not the place that they find a job to earn a living. Therefore, the managers and broadcasters of Rakom must have another profession as a backrest income, such as there are those who are teachers, traders, sellers, workers, farmers, fishermen, and so on.

When they are asked what their motives being involved in Rakom as a manager, announcer or listener (fans), there are some underlying motives, among others are due to: (1) hobbies of broadcasting and listening to the radio as a form of entertainment for themselves and their pleasure because it can provide information and entertainment for the community; (2) there is an ideal goal for people who want to be realized, such as helping farmers to improve the quality of agricultural products and their welfare; and (3) the desire to help people cope with the problems that occur, for example, to resolve the problem of domestic violence (domestic violence) and human trafficking.

From these findings it can be concluded that the voluntarism becomes the soul of the managers in running community radio. Their involvement in community radio is selfless and they put forward the interests of the public into their social capital to continue to maintain a community radio station that still exist and provide benefits to society.

According Schroender (1998; Ryan et al. 2001 in Hutapea and Goddess 2012, p.16o) volunteers are individuals who are willing to donate labor or services, capabilities, without a wage financially or without expecting any material gain from service organizations to organize a particular activity formally. Volunteers are in charge of serving others, providing many benefits and goodness to many parties and people, such as public health, social ties were tightened, increasing the confidence (trust) and the norms of reciprocity in the community without expecting to get rewards and compensation. In other words, the job of being a volunteer is to give something for others. Hence, volunteers get 'something' of activities to serve and help others. 'Something' is certainly a benefit.
Meanwhile, the idea of social capital is that a person can do 'investment' socially as well as economically. Social capital can be seen as an 'adhesive' which unites the community - relationships between people, people do what they do to each other because of their social obligation and reciprocity, social solidarity and community (Ife and Tesoriero 2008, p.35).

Further Ife and Tesoriero say that part of building social capital formation is to strengthen civil society. Civil society is a term used for the structures established formal or semiformal people voluntarily, on their own initiative and not as a consequence of a program or a specific direction from the government.

This thinking is in line with the contribution to society that views Rakom as a strategic program by Claude Ondobo UNESCO in the foreword to the book Community Radio Handbook (2001). The following is further explanation,

UNESCO sees community radio as a medium that gives voice to the voiceless, that serves as the mouthpiece of the marginalized and is at the heart of communication and democratic processes within societies. With community radio, citizens have the means to make their views known on decisions that concern them. The notions of transparency and good governance take on new dimensions and democracy is reinforced. Community radio catalyzes the development efforts of rural folk and the underprivileged segments of urban societies, given its exceptional ability to share timely and relevant information on development issues, opportunities, experiences, life skills and public interests. Given the audience's low literacy rate and radio's ability to involve women and to treat them not only as object or merely as a target audience, but as participating agents and as a valuable source, community radio becomes one of the most promising tools for community development(Ondobo in Colin and Estrada 2001).

From the Ondobo's description, it is clear that community radio is a medium 
which gives voice to those who have no voice, which gives funnel to those who are marginalized and become the heart of the communication and democratic processes in the society. With community radio, citizens have a way to use their own views in making decisions centered on them.

The idea of transparency and good governance (good governance) contains a new dimension and democracy that has been strengthened. Community radio is also a catalyst for development efforts on rural communities and disadvantaged groups in urban society, and also gives a remarkable ability to share relevant information on developing issues, opportunities, experiences, life skills (life skills) and the interests of the public.

Community radio audience involves a low average literacy and women by treating them not as objects, but as agents of participation and valuable resources. Therefore, the community radio is one tool that is able to promote community development.

\section{CONCLUSION}

Community radio is one the media that has the potential and strategic function to help overcoming the problems in the community and develop communities.

This paper examines the phenomenon in three community radio stations that become members of Jarik III Cirebon especially where the existence of Rakom is to help alleviating the problems of society.

The review is based on voluntarism perspective that describes the findings that: the backgrounds of the establishment, purpose and operation of community radio are based on socio-demographic conditions of the community; community-based social services as the spirit of community radio managers in meeting the needs of the community; and the principle of voluntarism Rakom manager's performance in helping people overcoming various problems become social capital for the formation of civil society based on the ability and initiative to develop the community.

\section{REFERENCES}

Azarya, V., 200o. "Community (Komunitas)". Kuper, Adam dan Kuper, Jessica. Ensiklopedi IlmuIlmu Sosial. PT Raja Grafindo Persada, Jakarta.

Birowo, A., Prakoso, I. \& Nasir. 2007. Mengapa Radio Komunitas. JRKI, Jakarta.

Bosch, T.E., 2007. Sustaining Community Radio Stations. e-journal online, 5(4), pp.27-29.

Creswell, J.W., 2013. Qualitative Inquiry $\mathcal{E}$ Research Design: Choosing Among Five Approaches. Sage Publication, Inc, Los Angeles.

Forbes, K.F. and Zampelli, E.M., 2014. Volunteerism: The influences of social, religious, and human capital. Nonprofit and Voluntary Sector Quarterly, 43(2), pp.227-253.

Fraser, C. \& Sonia, R.E., 2001. Community Radio Handbook. UNESCO.

Harvey, J., Lévesque, M. and Donnelly, P., 2007. Sport volunteerism and social capital. Sociology of Sport Journal, 24(2), pp.206-223.

Haryanto, I. \& Juventius J.R., 2009. Dinamika Radio Komunitas. LSSP dan Yayasan Tifa, Jakarta.

http://jrkjawabarat.blogspot.com/.

http://paramadina.ac.id/article:memberdayakankomunitas-lewat-radio:berita.

Hutapea, B. \& Fransisca I.R.D. 2012. Peran Kebermaknaan Hidup dan Kepemimpinan Melayani Terhadap Kepuasan Hidup Sukarelawan Lembaga Swadaya Masyarakat. Jurnal Insan. 14(3), pp.159-170.

Huvila, I., Holmberg, K., Ek, S. and Widén-Wulff, G., 2010. Social capital in second life. Online Information Review, 34(2), pp.295-316.

Ife, J. \& Frank T., 2008. Community Development: Alternatif Pengembangan Masyarakat di Era Globalisasi. Penerjemah: Sastrawan Manullang, Nurul Yakin, dan M. Nursyahid. Pustaka Pelajar, Yogyakarta: .

Jankowski, N.W. \& Prehn, O., (eds.) 2002. Community Media in the Information Age: Perspectives and Prospects. Hampton Press, Inc, Creskill, New Jersey.

Jurriëns, E., 2003. Radio Komunitas di Indonesia: 'New Brechtian Theatre' di Era Reformasi?. Antropologi Indonesia. 27(72), pp.116-130.

Lilis Ch., D., Yuliati , N. \& Rochim, M. ,2013. Mengusung Masyarakat Madani melalui Radio Komunitas. Mimbar. 29(2), pp.145-154.

Maring, P., Hasugian, F., Kaligis, R.A.W., 2015. Social Strategy of Ciliwung River Bank Community. Komunitas. 7(1), pp.102-111.

Miles, M.B. \& Huberman, M.A., 1992. Analisis Data Kualitatif: Buku Sumber Metode-Metode Baru. UI Press, Jakarta.

Mulyana, D \& Solatun. 2007. Metode Penelitian Komunikasi: Contoh-Contoh Penelitian Kualitatif dengan Pendekatan Praktis. PT Remaja Rosdakarya, Bandung.

Ondobo, C., 2001. Preface. Faser Colin dan Sonia Restrepo Estrada. Community Radio Handbook. UNESCO. 
Paik, A. and Navarre-Jackson, L., 2011. Social networks, recruitment, and volunteering: Are social capital effects conditional on recruitment? Nonprofit and Voluntary Sector Quarterly, 4o(3), pp.476-496.

Rochwulaningsih, Y. 2015. The Role of Social and Cultural Values in Public Education in Remote Island: Case Study in Karimunjawa Islands, Indonesia. Komunitas, 7(1)pp.25-36.

Sandoval, M., 2009. A Critical Contribution to the Foundations og Alternative Media Studies. International Journal of Communication Studies. 1(2009), pp.1-18.

Saxton, G.D. and Benson, M.A., 2005. Social capital and the growth of the nonprofit sector. Social Science Quarterly. 86(1), pp.16-35.

Stukas, A.A., Daly, M. and Cowling, M.J., 2005. Volunteerism and social capital: A functional approach. Australian Journal on Volunteering. 10(2), pp.35.

Tang, F., 2006. What resources are needed for volunteerism? A life course perspective. Journal of Applied Gerontology. 25(5), pp.375-
390.

Tucker, E. 2013. Community Radio in Political Theory and DevelopmentPractice. Journal of Development and Communication Studies. 2(3), pp.392-420.

Undang-Undang Dasar (UUD) 1945

Undang-Undang No. 32 Tahun 2002 tentang Penyiaran.

Wahyu. 2011. Masalah dan Usaha Membangun Karakter Bangsa. Jurnal Komunitas.3(2), pp.138-149.

Weisinger, J.Y. and Salipante, P.F., 2005. A grounded theory for building ethnically bridging social capital in voluntary organizations. Nonprofit and Voluntary Sector Quarterly. 34(1), pp.2955 .

Welty Peachey, J., Cohen, A., Borland, J. and Lyras, A., 2013. Building social capital: Examining the impact of Street Soccer USA on its volunteers. International Review for the Sociology of Sport. 48(1), pp.20-37.

Wilson, J., 2012. Volunteerism research: A review essay. Nonprofit and Voluntary Sector Quarterly. 